\title{
N-n-OCTYLANILINE AS A NEW REAGENT FOR ANALYTICAL LIQUID-LIQUID EXTRACTION OF YTTRIUM(III) FROM MATRICES OF VARIOUS METAL IONS
}

\author{
Balasaheb N. Kokare, Aniruddha M. Mandhare, Sanjay S. Kolekar, \\ Mansing A. Anuse* \\ Analytical Chemistry Laboratory, Department of Chemistry, Shivaji University, \\ Kolhapur, 416004 India \\ *mansinganuse@yahoo.co.in
}

\begin{abstract}
A systematic study of solvent extraction behavior of yttrium(III) with $N$ - $n$-octylaniline from salicylate media was carried out. Yttrium(III) was quantitatively extracted from $0.02-0.05 \mathrm{~mol} \mathrm{dm}^{-3} \mathrm{NaSal}$ at $\mathrm{pH} 9.7-10.5$ with $0.17 \mathrm{~mol} \mathrm{dm}^{-3} \mathrm{~N}-n$-octylaniline in xylene. The extraction was found to proceed by an anion exchange mechanism with the extraction species being $\left[\mathrm{CH}_{3}\left(\mathrm{CH}_{2}\right)_{7}\left(\mathrm{C}_{6} \mathrm{H}_{5}\right) \mathrm{NH}_{2}+\mathrm{Y}_{(}\left(\mathrm{C}_{7} \mathrm{H}_{4} \mathrm{O}_{3}\right)_{2}^{-}\right]$ascertained on the basis of slope analysis. The extracted metal ion was separated by selective stripping with hydrochloric acid or perchloric acid from the metal loading organic phase and estimated spectrophotometrically following a complexation with Alizarin Red S. A binary separation of yttrium(III) from Th(IV), $\mathrm{U}(\mathrm{VI}), \mathrm{Zr}(\mathrm{IV}), \mathrm{Nb}(\mathrm{V}), \mathrm{La}(\mathrm{III}), \mathrm{Nd}(\mathrm{III}), \mathrm{Ce}(\mathrm{IV})$ and $\mathrm{Gd}(\mathrm{III})$ is discussed.
\end{abstract}

Keywords: yttrium(III); $N$ - $n$-octylaniline; solvent extraction; salicylate

\section{$N$ - $n$-ОКТИЛАНИЛИН КАКО НОВ РЕАГЕНС ЗА АНАЛИТИЧКА ТЕЧНО-ТЕЧНА ЕКСТРАКЦИЈА НА ИТРИУМ(ІІІ) ОД МАТРИЦИ НА РАЗНИ МЕТАЛНИ ЈОНИ}

Направена е систематска студија на однесување на итриум(III) при екстракција со $N$-nоктиланилин од салицилатен медиум. Итриум(III) беше квантитативно екстрахиран од $0,02-$ $0,05 \mathrm{~mol} \mathrm{dm}^{-3} \mathrm{NaSal}$ при $\mathrm{pH}=9,7$ до 10,5 co $0,17 \mathrm{~mol} \mathrm{dm}^{-3} \mathrm{~N}$-n-октиланилин во ксилен. Најдено е дека екстракцијата се одвива преку механизам на анјонска измена со екстракционите единки

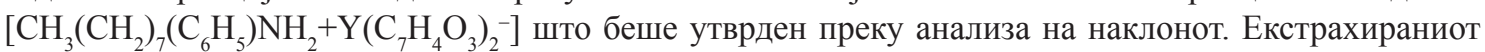
метален јон беше одделен со метод на селективно слекување со помош на хлороводородна или перхлорна киселина од метало-органската фаза и пресметан спектрофотометриски преку комплексирање со ализарин црвено S. Дискутирано е бинарното раздвојување на итриум(III) од Th(IV), U(VI), Zr(IV), Nb(V), La(III), Nd(III), Ce(IV) и Gd(III).

Клучни зборови: итриум(III); $N$-n-октиланилин; екстракција со растоворувач; салицилат 


\section{INTRODUCTION}

Solvent extraction is one of the most efficient methods for separation technology because of its simplicity, speed and applicability to both trace and macro amount of metal ions. Though there are various solvent extraction systems being used for metal ion separation, the ion-pair extraction systems have received much attention for a long time. Yttrium is an important element used in atomic reactors for the control rods. The separation of yttrium(III) from lanthanides remains a challenging problem because of their close similarities, i.e. similar ionic radii and coordination behaviour. Because of the importance of this element in nuclear energy programme, the separation and purification of yttrium is demanded. The preconcentration and purification of yttrium can be achieved by solvent extraction. Yttrium-90 is used for the production of labelled monoclonal antibodies for the tumour therapy studies.

A literature survey revealed that, over the years, various organophosphorus compounds have been effectively used for the extraction and separation of yttrium, these are, tributyl phosphine oxide (TBPO) [1], tris(2-ethylhexyl) phosphate (TEHP) [2], Cyanex 302 [3, 4], Cyanex $923[5,6]$, di(2-ethylhexyl) phosphoric acid [7-9], (2-ethylhexyl) phosphonic acid mono(2-ethylhexyl) ester (EHPNA) [10], secoctyl- phenoxy acetic acid (CA-12) and bis (2, 4, 4-trimethylpentyl) phosphinic acid (Cyanex 272, HL) [11]. Oxygen containing compounds also plays an important role for the liquid-liquid extraction of yttrium(III) such as CA-100 [12-14], dibenzo-18-crown-6 [15], (CA-12) [16], 2-bromoalkanoic acids [17], alkyl salicylic acids [18], 5,7-dichloro-8-hydroxyquinoline [19], carboxylic acid [20], $N, N^{\prime}$-dimethyl$N, N$ '-diphenylpyridine-2,6-dicarboxyamide (DMDPhPDA) [21], dialkyl sulphoxides [22], 5,11,17,23-tetra-tert-butyl-25,27-bis (diethylcarbamoyl methoxy)-26,28-dihydroxycalix [4] arene [23], calyx[4]arene [24]. There are very few studies published dealing with the extraction process of yttrium(III) with high molecular weight amines [25-30]. However, the existing methods suffers from limitations such as stringent control of $\mathrm{pH}[2,4,12,13,14,28]$, high reagent concentration $[8,17,25]$, long extraction time $[4,7,10,11,12,15,21,23,24]$, interference and co-extraction of other rare earths and associated metal ions $[1,2,4,9,14,16]$, need of masking agent to enhance the selectivity [10, 13]. In a few methods, there is requirement of synergism and salting out agents $[11,18,19$, $22,26,27,29,30]$ for quantitative extraction of yttrium(III).

Most of the work reported so far deals with the extraction of metals from mineral acid solutions. Relatively less information exists on the extraction of metals in these extractants from organic acid media. One of the distinct advantages of the organic acid media is the facility of controlling the concentration of complexing ligand, the ease of adjustment of $\mathrm{pH}$ and wide difference in $\mathrm{pH}$ at which various metal from anionic complexes. The comparative ease of stripping of the complexes from the organic phase can be achieved by fully exploiting the differences in reactivity of various metals to backwash in the aqueous phase by mineral acid. It is known that organic acid media offers better separation of metals possibly due to high stability of metal organic acids complexes. $N$ - $n$-octylaniline is a secondary amine; the presence of an octyl group attached to an amino group in aniline renders this amine less soluble in water. It has explored as an extractant for yttrium(III) in salicylate media, $N$ - $n$-octylaniline has its potential advantages with respect to lower cost, completely miscible with diluents and high purity. There is no emulsion formation and it has the potential of being prepared on large scale. Recently solvent extraction of palladium(II), antimony(III) with $N$-n-octylaniline from mineral acid [31, 32], platinum(IV), rhodium(III), zirconium(IV) from weak organic acid [33-35] and tellurium(IV) in halide [36] media has been reported, from the laboratory. The present work deals with a study of extraction of yttrium(III) and separation from some commonly associated metal ions such as, 
Th(IV), U(VI), Zr(IV), Nb(V), La(III), Nd(III), $\mathrm{Ce}(\mathrm{IV})$ and $\mathrm{Gd}(\mathrm{III})$ from salicylate media with $\mathrm{N}$ - $n$-octylaniline in xylene.

\section{EXPERIMENTAL}

\subsection{Reagents and apparatus}

A standard stock solution of yttrium(III) was prepared by dissolving $0.3175 \mathrm{~g}$ of yttrium oxide (dehydrated by ignition) in $5 \mathrm{~cm}^{3}$ of hot $\mathrm{HCl}(1: 1)$ and diluted to $250 \mathrm{~cm}^{3}$ with water. The solution was standardized [37] by known method and further diluted as required for the working solution. Alizarin red $\mathrm{S}$ (S.D. Fine chemicals) was prepared as a 0.1 $\%$ aqueous solution for the spectrophotometric determination of yttrium(III). The extractant $N$ $n$-octylaniline was prepared by the method of Gardlund's [38]. A solution of distilled aniline and $n$-octylbromide (3:1 molar ratio) was refluxed overnight. After cooling to room temperature, the reaction mixture was made basic with diluted aqueous ammonia. The aqueous layer was repeatedly washed with pentane. The pentane washing were combined with organic layer and treated with $50 \%$ aqueous $\mathrm{ZnCl}_{2}$ solution. Extraction of resulting solid with pentane, followed by drying with anhydrous potassium carbonate and flash evaporation of pentane yield crude $N$-n-octylaniline. Pure compound was obtained by fraction al distillation on a spinning band column. The yield and boiling range was as follows: $98.5 \%$, $177-178^{\circ} \mathrm{C}$ at $25 \mathrm{~mm}$ pressure. (Found C, 82.1; $\mathrm{H}, 11.4 ; \mathrm{C}_{14} \mathrm{H}_{23} \mathrm{~N}$ requires $\mathrm{C}, 81.9 ; \mathrm{H}, 11.3 \%$ ). The density of $N$ - $n$-octylaniline was found to be $0.89 \mathrm{~g} / \mathrm{cm}^{3}$. The $p$-toluensulphonyl derivative crystallized from alcohol in fan shaped cluster of needles, m.p. $42-43{ }^{\circ} \mathrm{C}$ (found: $\mathrm{N}, 4.1$; $\mathrm{C}_{21} \mathrm{H}_{29} \mathrm{O}_{2} \mathrm{NS}$ requires $\mathrm{N}, 3.8 \%$ ).

$0.17 \mathrm{~mol} \mathrm{dm}^{-3}$ solution of $N$-n-octylaniline in xylene was used for the proposed extraction procedure for yttrium(III).

All other chemicals (S.D. Fine) used in this work were of AR grade. Double distilled water was used throughout the procedure.
An Elico digital spectrophotometer model SL -171 with $1 \mathrm{~cm}$ quartz cells was used for absorbance measurements and $\mathrm{pH}$ measurements carried out using an Elico digital $\mathrm{pH}$ meter model LI-120.

\subsection{Procedure of extraction and determination of yttrium(III)}

An aliquot of $2 \mathrm{ml}$ yttrium(III) solution $\left(75 \mu \mathrm{g} / \mathrm{cm}^{3}\right)$ was mixed with of sodium salicylate $(0.120 \mathrm{~g})$ to make its concentration 0.03 $\mathrm{mol} \mathrm{dm}$ in a total volume of $25 \mathrm{ml}$ of the solution. The $\mathrm{pH}$ of the aqueous solution was adjusted to 10.3 with diluted $\mathrm{HCl}$ and $\mathrm{NaOH}$ solution. The solution was then transferred to a 125 $\mathrm{cm}^{3}$ separating funnel and shaken with $10 \mathrm{~cm}^{3}$ of $0.17 \mathrm{~mol} \mathrm{dm}^{-3} \mathrm{~N}$-n-octylaniline in xylene for 5 min. After separating the phases, the aqueous phase was discarded and the organic phase was stripped with two $10 \mathrm{~cm}^{3}$ portions of $0.05 \mathrm{~mol}$ $\mathrm{dm}^{-3} \mathrm{HCl}$. The combined aqueous phase was equilibrated with $5 \mathrm{~cm}^{3}$ of xylene to remove the traces of dissolved amine and evaporated to moist dryness and determined spectrophotometrically with alizarin red S [39].

The slightly acidic solution was transferred to a $25 \mathrm{~cm}^{3}$ volumetric flask followed by $2 \mathrm{~cm}^{3}$ of acetate buffer solution (pH 4.7) and 5 $\mathrm{cm}^{3}$ of $0.1 \%$ alizarin red $\mathrm{S}$ and diluted to the mark. The absorbance was measured at $535 \mathrm{~nm}$ against the reagent blank in the reference cell.

\section{RESULTS AND DISCUSSION}

\subsection{Effect of extraction condition}

The effect of $\mathrm{pH}$ on yttrium(III) extraction recovery, $\mathrm{R}(\%)$, was studied within the $\mathrm{pH}$ range of 1 to 11 in the presence of weak organic acid as a NaSal $\left(0.03 \mathrm{~mol} \mathrm{dm}^{-3}\right)$. The extraction started at $\mathrm{pH} 3.0$ and after that extraction of yttrium(III) increased with the increases of $\mathrm{pH}$ and became quantitative within $\mathrm{pH}$ range $9.7-$ 10.5 (Figure1). Therefore, the value of $\mathrm{pH} 10.3$ was selected for the recommended procedure. 


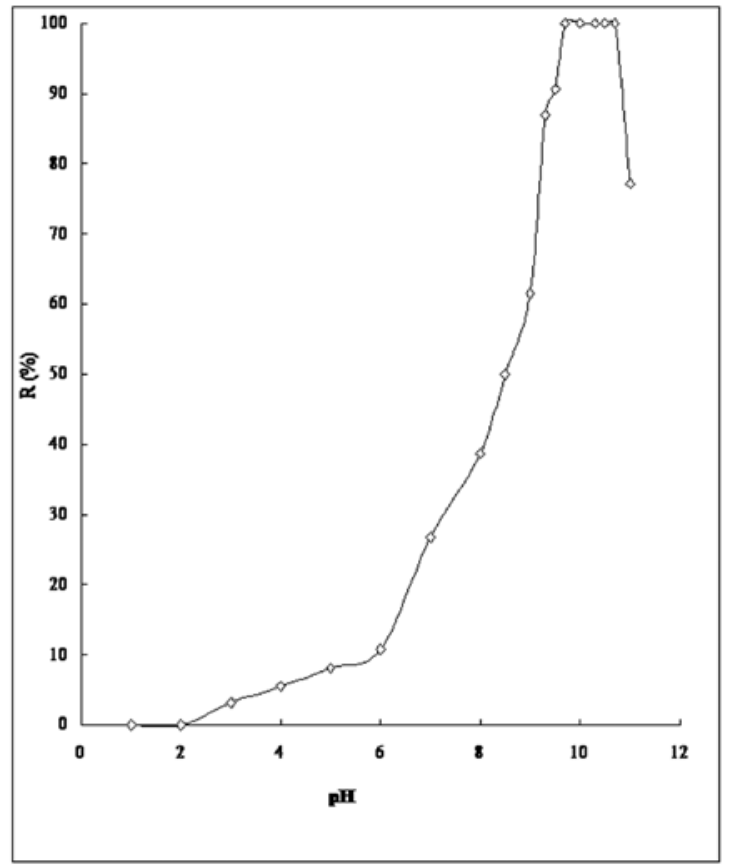

Fig. 1. Extraction behaviour of yttrium(III) as a function of $\mathrm{pH}$ from $0.03 \mathrm{~mol} \mathrm{dm}^{-3} \mathrm{NaSal}$ with $0.17 \mathrm{~mol} \mathrm{dm}^{-3}$ $N$-n-octylaniline, $\gamma\left(\mathrm{Y}^{3+}\right)=150 \mu \mathrm{g} / 25 \mathrm{~cm}^{3}$
The influence of $N$ - $n$-octylaniline concentration on the extraction recovery of yttrium(III) was investigated by varying with concentration of this reagent dissolved in xylene of 0.0002 to $0.64 \mathrm{~mol} \mathrm{dm}^{-3}$. It was found that $10 \mathrm{~cm}^{3}$ of $0.13 \mathrm{~mol} \mathrm{dm}^{-3} N$-n-octylaniline was quite needed for the complete extraction of yttrium(III) from $0.03 \mathrm{~mol} \mathrm{dm}^{-3} \mathrm{NaSal}$, but to ensure the complete extraction of metal ion by the recommended procedure as an optimal concentration of $N$ - $n$-octylaniline in xylene was used $0.17 \mathrm{~mol} \mathrm{dm}^{-3}$ (Table 1A).

The extraction of yttrium(III) was investigated at $\mathrm{pH} 10.3$ with $0.17 \mathrm{~mol} \mathrm{dm}^{-3}$ $N$ - $n$-octylaniline in xylene in the presence of varying concentration from 0.005 to $0.1 \mathrm{~mol} \mathrm{dm}^{-3}$ sodium succinate, sodium salicylate, sodium malonate, sodium citrate and ascorbic acid (S.D. Fine) as a weak acid media. It is evident from data in Table 1B that yttrium(III) was extracted incompletely from

$\mathrm{T}$ a b l e $1 \mathrm{~A}$

Extraction behaviour of yttrium(III) as a function of $N$-n-octylaniline concentration $\gamma\left(\mathrm{Y}^{3+}\right)=150 \mu \mathrm{g} / 25 \mathrm{~cm}^{3}, \mathrm{pH}=10.3, c$ (sodium salicylate) $=0.03 \mathrm{~mol} \mathrm{dm}^{-3}$, Aq : Org $=25: 10 \mathrm{~cm}^{3}: \mathrm{cm}^{3}$, Strippant $=0.05 \mathrm{~mol} \mathrm{dm}^{-3} \mathrm{HCl}\left(2 \times 10 \mathrm{~cm}^{3}\right)$, equilibrium time $=5 \mathrm{~min}$

\begin{tabular}{ccc}
\hline \hline $\begin{array}{c}\text { Concentration of } \\
N \text { - } n \text {-octylaniline } / \mathrm{mol} \mathrm{dm}^{-3}\end{array}$ & $\begin{array}{c}\mathrm{R} \\
(\%)\end{array}$ & $\begin{array}{c}\text { Distribution } \\
\text { ratio D }\end{array}$ \\
\hline 0.0002 & 25.0 & 0.83 \\
0.0004 & 33.3 & 1.25 \\
0.0022 & 54.3 & 2.97 \\
0.0030 & 59.0 & 3.60 \\
0.0044 & 69.7 & 5.75 \\
0.022 & 74.7 & 7.38 \\
0.031 & 77.1 & 8.42 \\
0.043 & 84.8 & 13.95 \\
0.087 & 93.1 & 33.73 \\
0.11 & 95.2 & 49.58 \\
0.13 & 100 & $\infty$ \\
0.17 & 100 & $\infty$ \\
0.22 & 100 & $\infty$ \\
0.43 & 100 & $\infty$ \\
0.64 & 100 & $\infty$ \\
\hline \hline
\end{tabular}


$\mathrm{Ta} \mathrm{b}$ le 1B

Extraction behaviour of yttrium(III) as a function of of the concentration of the weak organic acids $\gamma\left(\mathrm{Y}^{3+}\right)=150 \mu \mathrm{g} / 25 \mathrm{~cm}^{3}, \mathrm{pH}=10.3$, extractant $=0.17 \mathrm{~mol} \mathrm{dm}{ }^{-3} N$ - $n$-octylaniline in xylene $\left(10 \mathrm{~cm}^{3}\right)$, Aq : Org $=25: 10 \mathrm{~cm}^{3}: \mathrm{cm}^{3}$, Strippant $=0.05 \mathrm{~mol} \mathrm{dm}{ }^{-3} \mathrm{HCl}\left(2 \times 10 \mathrm{~cm}^{3}\right)$, equilibrium time $=5 \mathrm{~min}$

\begin{tabular}{ccccccccccc}
\hline \hline \multirow{2}{*}{$c / \mathrm{mol} \mathrm{dm}^{-3}$} & \multicolumn{2}{c}{$\begin{array}{c}\text { Sodium } \\
\text { succinate }\end{array}$} & \multicolumn{2}{c}{$\begin{array}{c}\text { Sodium } \\
\text { salicylate }\end{array}$} & \multicolumn{2}{c}{$\begin{array}{c}\text { Sodium } \\
\text { malonate }\end{array}$} & \multicolumn{2}{c}{$\begin{array}{c}\text { Ascorbic } \\
\text { acid }\end{array}$} & \multicolumn{3}{c}{$\begin{array}{c}\text { Sodium } \\
\text { citrate }\end{array}$} \\
\hline & $\mathrm{R}(\%)^{\mathrm{a}}$ & $\mathrm{D}^{\mathrm{b}}$ & $\mathrm{R}(\%)$ & $\mathrm{D}$ & $\mathrm{R}(\%)$ & $\mathrm{D}$ & $\mathrm{R}(\%)$ & $\mathrm{D}$ & $\mathrm{R}(\%)$ & $\mathrm{D}$ \\
\hline 0.00 & 20.8 & 0.66 & 20.8 & 0.65 & 20.8 & 0.65 & 20.8 & 0.65 & 20.8 & 0.65 \\
0.005 & 89.0 & 20.23 & 53.3 & 2.84 & 74.3 & 7.22 & 25.0 & 0.83 & 21.3 & 0.70 \\
0.01 & 77.6 & 8.66 & 75.6 & 7.75 & 79.3 & 9.58 & 32.0 & 1.17 & 27.6 & 0.95 \\
0.02 & 65.2 & 4.68 & 100 & $\infty$ & 75.3 & 7.62 & 32.9 & 1.23 & 31.2 & 1.13 \\
0.03 & 63.3 & 4.31 & 100 & $\infty$ & 54.2 & 2.96 & 35.9 & 1.40 & 32.9 & 1.23 \\
0.04 & 60.1 & 3.77 & 100 & $\infty$ & 50.0 & 2.50 & 38.7 & 1.58 & 34.3 & 1.30 \\
0.05 & 54.6 & 3.00 & 100 & $\infty$ & 46.2 & 2.15 & 42.0 & 1.81 & 36.9 & 1.46 \\
0.06 & 51.7 & 2.67 & 86.7 & 16.33 & 36.5 & 1.44 & 47.3 & 2.47 & 46.7 & 2.19 \\
0.07 & 47.0 & 2.21 & 70.5 & 5.97 & 32.9 & 1.22 & 46.4 & 2.16 & 54.8 & 3.03 \\
0.08 & 44.2 & 1.98 & 68.3 & 5.39 & 29.5 & 1.05 & 37.1 & 1.47 & 44.8 & 2.03 \\
0.09 & 42.0 & 1.81 & 62.8 & 4.21 & 27.1 & 0.93 & 32.1 & 1.84 & 38.1 & 1.54 \\
0.1 & 40.7 & 1.71 & 46.3 & 2.16 & 23.5 & 0.77 & 29.0 & 0.98 & 31.0 & 1.12 \\
\hline \hline
\end{tabular}

$\mathrm{a}$ - percentage of extraction recovery, $\mathrm{b}$ - distribution ratio

$\mathrm{T}$ a b 1 e $1 \mathrm{C}$

\section{Extraction behaviour of yttrium(III) as a function of diluents}

$\gamma\left(\mathrm{Y}^{3+}\right)=150 \mu \mathrm{g} / 25 \mathrm{~cm}^{3}, \mathrm{pH}=10.3$, extractant $=0.17 \mathrm{~mol} \mathrm{dm}^{-3} N$ - $n$-octylaniline in xylene $\left(10 \mathrm{~cm}^{3}\right)$, $c($ sodium salicylate $)=0.03 \mathrm{~mol} \mathrm{dm}{ }^{-3}, \mathrm{Aq}: \operatorname{Org}=25: 10 \mathrm{~cm}^{3}: \mathrm{cm}^{3}$,

Strippant $=0.05 \mathrm{~mol} \mathrm{dm}^{-3} \mathrm{HCl}\left(2 \times 10 \mathrm{~cm}^{3}\right)$, equilibrium time $=5 \mathrm{~min}$

\begin{tabular}{lccc}
\hline \hline Diluent & $\begin{array}{l}\text { Dielectric } \\
\text { constant } \varepsilon\end{array}$ & $\mathrm{R}(\%)$ & $\begin{array}{c}\text { Distribution ratio } \\
\mathrm{D}\end{array}$ \\
\hline Benzene & 2.28 & 95.8 & 57.02 \\
Toluene & 2.38 & 100 & $\infty$ \\
Xylene & 2.30 & 100 & $\infty$ \\
Carbon tetrachloride & 2.24 & 83.5 & 12.65 \\
Chloroform & 4.81 & 92.4 & 30.57 \\
Kerosene & 1.80 & 73.0 & 6.75 \\
Methyl isobutyl ketone & 13.11 & 70.0 & 5.83 \\
n-Butanol & 17.80 & 85.9 & 15.21 \\
Amyl alcohol & 13.90 & 66.0 & 4.85 \\
1, 2-Dichloroethane & 10.5 & 85.5 & 14.71 \\
\hline \hline
\end{tabular}


sodium succinate, sodium malonate, L-ascorbic acid and sodium citrate media. The quantitative extraction of yttrium(III) expressed by R (\%) was found to be in the range of $0.02-0.05 \mathrm{~mol}$ $\mathrm{dm}^{-3} \mathrm{NaSal}$. Therefore, $0.03 \mathrm{~mol} \mathrm{dm}^{-3}$ was used for further experimental investigations.

The formation of very stable complexes of yttrium(III) with NaSal prior to solvent extraction is a prerequisite.

The extraction of yttrium(III) was carried out with various solvents (S.D. Fine) (probably NOA was dissolved in various solvents). It was found that xylene is the most adequate solvent for quantitative extraction of yttrium(III) and preferred as a diluent for further extraction procedure (Table 1C).

\subsection{Nature of extracted species}

The nature of extracted species was ascertained by using $\log D-\log C$ plots. The graphs of $\log D_{[\mathrm{Y}(\mathrm{III})]}$ against $\log C_{[N-n \text {-octylaniline] }}$ at fixed NaSal concentration $\left(0.03 \mathrm{~mol} \mathrm{dm}^{-3}\right)$ were found to be linear and having slope values of 0.80 and 0.97 at $\mathrm{pH} 9.0$ and 9.3, respectively (Figure 2A).

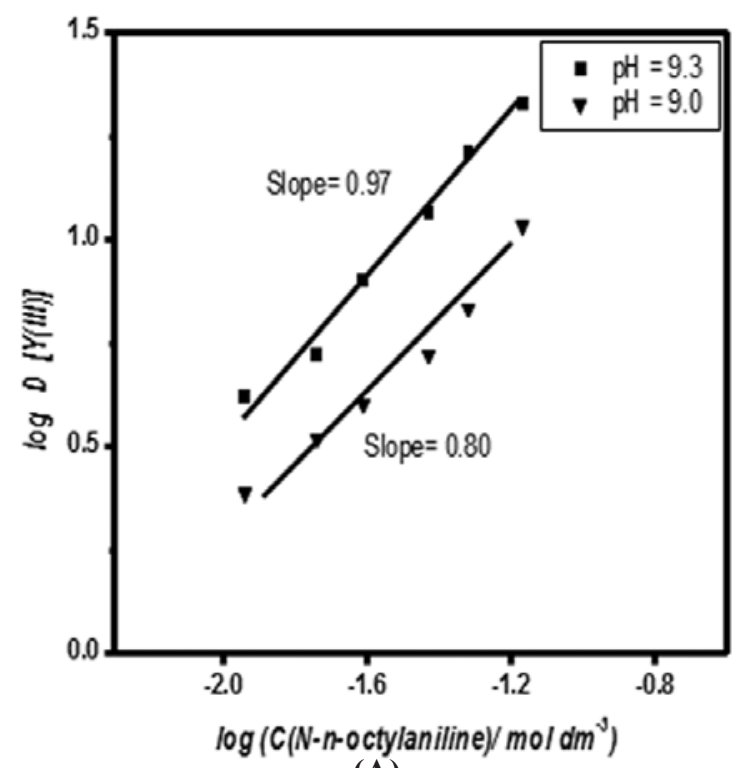

(A)
Also plots of $\log D_{[\mathrm{Y}(\mathrm{IIII}]}$ against $\log C_{\text {[salicylate] }}$ at fixed $N$-n-octylaniline concentration $\left(0.17 \mathrm{~mol} \mathrm{dm}^{-3}\right)$ were linear and slope values were found to be 1.75 and 2.05 at pH 9.0 and 9.3, respectively (Figure $2 \mathrm{~B}$ ). This indicates a mole ratio of yttrium(III) with respect to $N$ - $n$-octylaniline as $1: 1$ and that of salicylate is $1: 2$. The nature of extracted species was found to be, $1: 2: 1$ (metal : acid : extractant).

The probable mechanism of the formation of ion-pair complex as follows:.

$\mathrm{Y}^{3+}(a q)+2 \mathrm{C}_{7} \mathrm{H}_{4} \mathrm{O}_{3}{ }^{2-}(a q)=\left[\mathrm{Y}\left(\mathrm{C}_{7} \mathrm{H}_{4} \mathrm{O}_{3}\right)_{2}\right]^{-}(a q)$

Then this complex reacts with $N$ - $n$-octylanilinium cation, $\mathrm{CH}_{3}\left(\mathrm{CH}_{2}\right)_{7}\left(\mathrm{C}_{6} \mathrm{H}_{5}\right) \mathrm{NH}_{2}^{+}$, dissolved in xylene as follows:

$$
\begin{aligned}
& \mathrm{RPh} \mathrm{NH}_{2}^{+}(\text {org })+\left[\mathrm{Y}\left(\mathrm{C}_{7} \mathrm{H}_{4} \mathrm{O}_{3}\right)_{2}\right]^{-}(a q)= \\
& {\left[\mathrm{RPh} \mathrm{NH}_{2}^{+} \mathrm{Y}\left(\mathrm{C}_{7} \mathrm{H}_{4} \mathrm{O}_{3}\right)_{2}^{-}\right] \text {(org) }}
\end{aligned}
$$

The back extraction process would be

$$
\begin{gathered}
{\left[\mathrm{RPh} \mathrm{NH}_{2}^{+} \mathrm{Y}\left(\mathrm{C}_{7} \mathrm{H}_{4} \mathrm{O}_{3}\right)_{2}{ }^{-}\right](\text {org })+3 \mathrm{HCl}(\text { aq })} \\
=\mathrm{RPh} \mathrm{NH}^{+}(\text {org })+\mathrm{YCl}_{3}(\text { aq })+2 \mathrm{C}_{7} \mathrm{H}_{6} \mathrm{O}_{3}(\text { org }) \\
\mathrm{R}=\mathrm{CH}_{3}\left(\mathrm{CH}_{2}\right)_{7}, \mathrm{Ar}=\mathrm{C}_{6} \mathrm{H}_{5}
\end{gathered}
$$

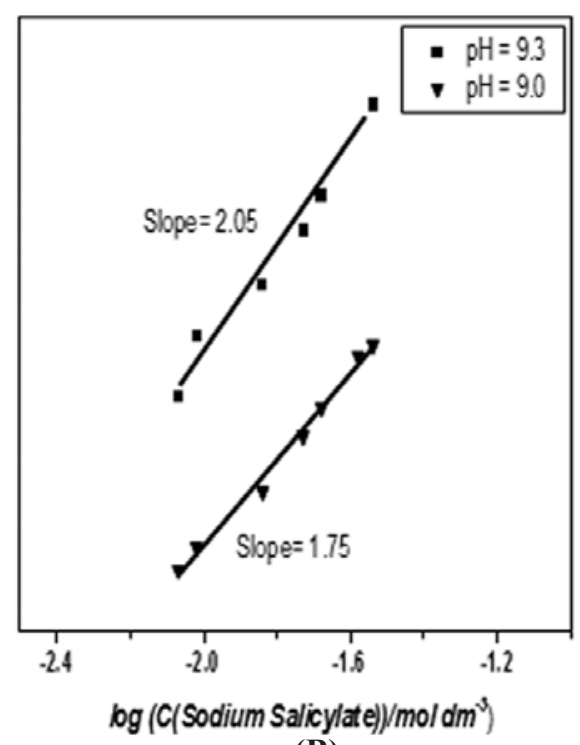

(B)

Fig. 2 (A) Log-log plot of $\log D_{[Y(I I I)]}$ against $\log \left(\mathrm{c}(\mathrm{N}\right.$-n-octylaniline $\left.) / \mathrm{mol} \mathrm{dm^{-3 }}\right)$ at fixed NaSal concentration $\left(0.03 \mathrm{~mol} \mathrm{dm^{-3 }}\right), \gamma\left(Y^{3+}\right)=150 \mu \mathrm{g} / 25 \mathrm{~cm}^{3}, \mathrm{pH} 9.0$ and 9.3

(B) Log-log plot of $\log D_{[Y(I I I)]}$ against $\log \left(\mathrm{c}(\mathrm{NaSal}) / \mathrm{mol} \mathrm{dm^{-3 } )}\right.$ at fixed $\mathrm{N}$-n-octylaniline concentration $\left(0.17 \mathrm{~mol} \mathrm{dm^{-3 }}\right), \gamma\left(Y^{3+}\right)=150 \mu \mathrm{g} / 25 \mathrm{~cm}^{3}, \mathrm{pH} 9.0$ and 9.3 


\subsection{Effect of stripping agents}

It was found that, two $10 \mathrm{~cm}^{3}$ portions of $\mathrm{HCl}\left(0.03-0.06 \mathrm{~mol} \mathrm{dm}^{-3}\right)$, and $\mathrm{HClO}_{4}(0.06$ $-0.07 \mathrm{~mol} \mathrm{dm}^{-3}$ ) were useful for quantitative stripping of yttrium(III) from the organic phase. Acetate buffer ( $\mathrm{pH} 4.27)$ and water become unsuccessful for the recovery of yttrium(III) from organic solution (Table 1D). In actual practice, two $10 \mathrm{~cm}^{3}$ portion of $0.03 \mathrm{~mol} \mathrm{dm}^{-3} \mathrm{HCl}$ were found to be suitable stripping agent.

\subsection{Effect of equilibration time, loading capa-} city of $N$-n-octylaniline, and effect of aqueous to organic volume ratio

The results indicate that the extraction is fast and 4 minute equilibrium time is adequate for quantitative extraction of yttrium(III). In general procedure, $5 \mathrm{~min}$. equilibrium time was recommended in order to ensure the complete extraction of metal ion.

The loading capacity of the extractant was determined by the repeated contact of the organic phase with a fresh feed solution of the metal of various concentrations. For a $10 \mathrm{~cm}^{3}$, $0.17 \mathrm{~mol} \mathrm{dm}^{-3}$ solution of $N$-n-octylaniline in xylene at $0.03 \mathrm{~mol} \mathrm{dm}^{-3} \mathrm{NaSal}$ concentration and at aq/org phase ratio of $2.5: 1$, the maximum loading capacity for yttrium(III) was found to be $400 \mu \mathrm{g}$.

Results of contacting different volume ratios of aqueous $(a q)$ to organic phase (org) indicate that a preferred aq/org phase ratio exists for the system under study, and this was found to be $5: 1$ or less. This is evident from the sharp increase in the separation factor as well as the distribution ratio of yttrium(III), when phase ratio aq/org was changed from $50: 1$ to $6: 1$. However, in the recommended procedure, the phase ratio used is $2.5: 1\left(25: 10 \mathrm{~cm}^{3}: \mathrm{cm}^{3}\right)$, to avoid the large consumption of the NaSal.

\subsection{Effect of diverse ions}

The effect of various cations and anions in the separation and determination of yttrium(III) was studied by the recommended procedure

$\mathrm{T}$ a b le 1D

Extraction behaviour of yttrium(III) as a function of stripping agents $\gamma\left(\mathrm{Y}^{3+}\right)=150 \mu \mathrm{g} / 25 \mathrm{~cm}^{3}, \mathrm{pH}=10.3$, extractant $=0.17 \mathrm{~mol} \mathrm{dm}-3$-n-octylaniline in xylene $\left(10 \mathrm{~cm}^{3}\right)$,
$c($ sodium salicylate $)=0.03 \mathrm{~mol} \mathrm{dm}-3, \mathrm{Aq}:$ Org $=25: 10 \mathrm{~cm}^{3}: \mathrm{cm}^{3}$,
Strippant $=0.05 \mathrm{~mol} \mathrm{dm}{ }^{-3} \mathrm{HCl}\left(2 \times 10 \mathrm{~cm}^{3}\right)$, equilibrium time $=5 \mathrm{~min}$

\begin{tabular}{cccccccc}
\hline \hline & $\mathrm{HCl}$ & $\mathrm{HClO}_{4}$ & $\mathrm{HNO}_{3}$ & $\mathrm{CH}_{3} \mathrm{COOH}$ & $\mathrm{H}_{2} \mathrm{SO}_{4}$ & $\mathrm{NH}_{4} \mathrm{Cl}$ & $\mathrm{KNO}_{3}$ \\
\cline { 2 - 8 }$c / \mathrm{mol} \mathrm{dm}^{-3}$ & $\mathrm{R}(\%)^{\mathrm{a}}$ & $\mathrm{R}(\%)$ & $\mathrm{R}(\%)$ & $\mathrm{R}(\%)$ & $\mathrm{R}(\%)$ & $\mathrm{R}(\%)$ & $\mathrm{R}(\%)$ \\
\hline 0.01 & 77.3 & 73.0 & 84.7 & 68.3 & 92.1 & 58.6 & 9.5 \\
0.02 & 90.6 & 77.1 & 53.2 & 69.1 & 80.7 & 60.4 & 2.8 \\
0.03 & 100 & 90.6 & 57.0 & 70.1 & 62.9 & 61.6 & 2.4 \\
0.04 & 100 & 95.1 & 74.1 & 73.0 & 44.6 & 62.5 & 15.4 \\
0.05 & 100 & 95.5 & 68.2 & 64.1 & 16.9 & 63.9 & 10.5 \\
0.06 & 100 & 99.0 & 64.6 & 60.8 & 00.0 & 66.3 & 15.6 \\
0.07 & 96.9 & 99.4 & 45.8 & 57.6 & 00.0 & 76.1 & 18.9 \\
0.08 & 93.4 & 98.2 & 42.6 & 52.6 & 00.0 & 79.1 & 20.1 \\
0.09 & 90.6 & 95.9 & 36.1 & 51.4 & 00.0 & 92.2 & 24.5 \\
0.10 & 85.4 & 94.3 & 31.8 & 47.6 & 00.0 & 96.6 & 25.0 \\
\hline \hline
\end{tabular}

Water $=4.0 \%$. Acetate buffer $(\mathrm{pH} 4.27)=67.1 \%$. a - Percentage of extraction recovery 
(Table 2). The tolerance limit was set by the amount of foreign ions causing a change $\pm 2 \%$ error in the recovery of yttrium(III). Interference due to $\mathrm{V}(\mathrm{V}), \mathrm{Zr}(\mathrm{IV}), \mathrm{Ce}(\mathrm{IV})$ and $\mathrm{Ti}(\mathrm{IV})$ were eliminated by masking with $10 \mathrm{mg} \mathrm{F}^{-}, \mathrm{Mn}(\mathrm{II})$ was masked with $5 \mathrm{mg}$ oxalate. EDTA, citrate and tartarate interfere.

\section{APPLICATIONS}

\subsection{Separation and determination} of yttrium(III) from binary mixtures

\subsubsection{Separation of yttrium(III) from Th(IV), $U(V I), \operatorname{Zr}(I V), N b(V), L a(I I I)$ and $N d(I I I)$}

It was found that, metal ions (S.D. Fine) such as $\mathrm{Th}(\mathrm{IV}), \mathrm{U}(\mathrm{VI}), \mathrm{Zr}(\mathrm{IV}), \mathrm{Nb}(\mathrm{V}), \mathrm{La}(\mathrm{III})$ and $\mathrm{Nd}(\mathrm{III})$ remained unextracted under the optimum extraction condition of yttrium(III) using $0.03 \mathrm{~mol} \mathrm{dm}^{-3} \mathrm{NaSal}$ with $10 \mathrm{~cm}^{3} 0.17$ mol $\mathrm{dm}^{-3} N$-n-octylaniline in xylene. The yttrium(III) was stripped with $0.05 \mathrm{~mol} \mathrm{dm}^{-3}$ $\mathrm{HCl}\left(2 \times 10 \mathrm{~cm}^{3}\right)$ from organic phase and determined spectrophotometrically with alizarin red $\mathrm{S}$. The aqueous phase was washed with $5 \mathrm{~cm}^{3}$ xylene to remove traces of the reagent. Metal ions from aqueous phase were determined by standard procedure [39-43].

\subsubsection{Separation of yttrium(III) from $\mathrm{Ce}(\mathrm{IV})$}

The proposed method was also extended for separation of yttrium(III) from $\mathrm{Ce}(\mathrm{IV})$ by masking with $10 \mathrm{mg}$ of fluoride. The masked $\mathrm{T}$ a b 1 e 2

Effect of foreign ions on the extraction of $150 \mu \mathrm{g}$ yttrium(III) at pH $10.3 \mathrm{in} 0.03 \mathrm{~mol} \mathrm{dm}^{-3}$ sodium salicylate with $0.17 \mathrm{~mol} \mathrm{dm^{-3 }} \mathrm{N}$-n-octylaniline in xylene

\begin{tabular}{lllllc}
\hline \hline Foreign ion & Added as & $\begin{array}{l}\text { Tolerance } \\
\text { limit/mg }\end{array}$ & Foreign ion & Added as & $\begin{array}{c}\text { Tolerance } \\
\text { limit/mg }\end{array}$ \\
\hline $\mathrm{Ca}(\mathrm{II})$ & $\mathrm{CaCl}_{2}$ & 5.0 & $\mathrm{Nd}(\mathrm{III})$ & $\mathrm{Nd}_{2} \mathrm{O}_{3}$ & 0.3 \\
$\mathrm{Mg}(\mathrm{II})$ & $\mathrm{MgCl}_{2} \cdot 6 \mathrm{H}_{2} \mathrm{O}$ & 5.0 & $\mathrm{Sm}(\mathrm{III})$ & $\left.\mathrm{Sm}_{(\mathrm{NO}}\right)_{3} \cdot 6 \mathrm{H}_{2} \mathrm{O}$ & 0.3 \\
$\mathrm{Sr}(\mathrm{II})$ & $\left.\mathrm{Sr} \mathrm{NO}_{3}\right)_{2}$ & 3.0 & $\mathrm{Rh}(\mathrm{III})$ & $\mathrm{RhCl}_{3}$ & 0.2 \\
$\mathrm{Cr}(\mathrm{VI})$ & $\mathrm{K}_{2} \mathrm{Cr}_{2} \mathrm{O}_{7}$ & 3.0 & $\mathrm{Ce}(\mathrm{IV})^{\mathrm{a}}$ & $\mathrm{Ce}\left(\mathrm{SO}_{4}\right)_{2}$ & 0.2 \\
$\mathrm{Ni}(\mathrm{II})$ & $\mathrm{NiCl}_{2} \cdot 6 \mathrm{H}_{2} \mathrm{O}$ & 1.0 & $\mathrm{La}(\mathrm{III})$ & $\mathrm{La}_{2} \mathrm{O}_{3}$ & 0.2 \\
$\mathrm{~W}(\mathrm{VI})$ & $\mathrm{Na}_{2} \mathrm{WO}_{4} \cdot 2 \mathrm{H}_{2} \mathrm{O}$ & 1.0 & $\mathrm{Ti}(\mathrm{IV})^{\mathrm{a}}$ & $\mathrm{K}_{2} \cdot \mathrm{TiF}_{6} \cdot \mathrm{H}_{2} \mathrm{O}$ & 0.2 \\
$\mathrm{U}(\mathrm{VI})$ & $\mathrm{UO}_{2}\left(\mathrm{NO}_{3}\right)_{2} \cdot 6 \mathrm{H}_{2} \mathrm{O}$ & 1.0 & $\mathrm{Nb}(\mathrm{V})$ & $\mathrm{Nb}_{2} \mathrm{O}_{5}$ & 0.2 \\
$\mathrm{Ba}(\mathrm{II})$ & $\mathrm{BaCl}_{2} \cdot 2 \mathrm{H}_{2} \mathrm{O}$ & 0.5 & Thiourea & Thiourea & 50 \\
$\mathrm{Co}(\mathrm{II})$ & $\mathrm{CoCl}_{2} \cdot 6 \mathrm{H}_{2} \mathrm{O}$ & 0.5 & Bromide & Potassium bromide & 50 \\
$\mathrm{Mn}(\mathrm{II})^{\mathrm{b}}$ & $\mathrm{MnCl}_{2} \cdot 6 \mathrm{H}_{2} \mathrm{O}$ & 0.5 & Nitrate & Sodium nitrate & 50 \\
$\mathrm{Cd}(\mathrm{II})$ & $\mathrm{CdCl}_{2} \cdot 21 / 2 \mathrm{H}_{2} \mathrm{O}$ & 0.5 & Thiosulphate & Sodium thiosulphate & 25 \\
$\mathrm{Zn}(\mathrm{II})$ & $\mathrm{ZnSO}_{4} \cdot 7 \mathrm{H}_{2} \mathrm{O}$ & 0.5 & Malonate & Sodium malonate & 25 \\
$\mathrm{Pd}(\mathrm{II})$ & $\mathrm{PdCl}_{2}$ & 0.5 & Acetate & Sodium acetate & 25 \\
$\mathrm{Fe}(\mathrm{II})$ & $\mathrm{FeSO}_{4} \cdot 7 \mathrm{H}_{2} \mathrm{O}$ & 0.5 & Iodide & Potassium iodide & 25 \\
$\mathrm{~V}(\mathrm{~V})^{\mathrm{a}}$ & $\mathrm{NH}_{4} \cdot \mathrm{VO}_{3} \cdot \mathrm{H}_{2} \mathrm{O}$ & 0.5 & Nitrite & Sodium nitrite & 25 \\
$\mathrm{Mo}(\mathrm{VI})$ & $\left(\mathrm{NH}_{4}\right)_{6} \mathrm{Mo}_{7} \mathrm{O}_{24} \cdot 2 \mathrm{H}_{2} \mathrm{O}$ & 0.5 & Fluoride & Sodium fluoride & 15 \\
$\mathrm{Zr}(\mathrm{VI})$ & ${\mathrm{Zr}\left(\mathrm{NO}_{3}\right)_{4}}_{\mathrm{Ta}(\mathrm{V})}^{\mathrm{Ta}_{2} \mathrm{O}_{5}}$ & 0.3 & Ascorbate & Ascorbic acid & 1.0 \\
\hline \hline
\end{tabular}

${ }^{\mathrm{a}}$ masked with $10 \mathrm{mg} \mathrm{F}$, ${ }^{\mathrm{b}}$ Masked with $5 \mathrm{mg}$ oxalate 
$\mathrm{Ce}(\mathrm{IV})$ remained in the aqueous phase quantitatively. After demasking of Ce(IV) with $5 \mathrm{~cm}^{3}$ concentrated perchloric acid and evaporated to moist dryness, it was estimated spectrophotometrically with $0.1 \%$ arsenazo III at $535 \mathrm{~nm}$ [40]. Yttrium(III) was stripped from organic phase and determined.

\subsubsection{Separation of yttrium(III) from $G d(I I I)$}

Under the optimum extraction procedure of yttrium(III), Gd(III) was coextracted in the organic phase. However, yttrium(III) from the organic phase was back stripped with $0.05 \mathrm{~mol}$ $\mathrm{dm}^{-3} \mathrm{HCl}\left(2 \times 10 \mathrm{~cm}^{3}\right)$ while there is no back extraction of $\mathrm{Gd}(\mathrm{III})$. Yttrium(III) was determined via general procedure. Gadolinium(III) was stripped by $0.1 \mathrm{~mol} \mathrm{dm}^{-3} \mathrm{HClO}_{4}\left(2 \times 5 \mathrm{~cm}^{3}\right)$ and was determined spectrophotometrically [44] (Table 3).

\subsection{Separation of yttrium(III) from synthetic mixtures}

A solution containing $150 \mu \mathrm{g}$ yttrium(III) was taken and known amount of other metals were added. Amount of yttrium(III) was extracted under the optimum extraction conditions. The results obtained were in good agreement with the amount added (Table 4).

\section{CONCLUSION}

The developed method is simple, rapid, selective, reproducible and suitable for separa-

$\mathrm{T}$ a b 1 e 3

\section{Separation of yttrium(III) from binary mixtures}

$\gamma\left(\mathrm{Y}^{3+}\right)=150 \mu \mathrm{g} / 25 \mathrm{~cm}^{3}, \mathrm{pH}=10.3$, extractant $=0.17 \mathrm{~mol} \mathrm{dm}^{-3} \mathrm{~N}$ - $n$-octylaniline in xylene $\left(10 \mathrm{~cm}^{3}\right)$, $c($ sodium salicylate $)=0.03 \mathrm{~mol} \mathrm{dm}{ }^{-3}, \mathrm{Aq}: \mathrm{Org}=25: 10 \mathrm{~cm}^{3}: \mathrm{cm}^{3}$, strippant $=0.05 \mathrm{~mol} \mathrm{dm} \mathrm{dm}^{-3} \mathrm{HCl}\left(2 \times 10 \mathrm{~cm}^{3}\right)$, equilibrium time $=5 \mathrm{~min}$

\begin{tabular}{ccccc}
\hline \hline Metal ion & $\begin{array}{c}\text { Mass of metal } \\
\text { ion/ } \mu \mathrm{g}\end{array}$ & $\mathrm{R}(\%)^{\mathrm{b}}$ & $\begin{array}{c}\text { Chromogenic } \\
\text { ligand }\end{array}$ & $\begin{array}{c}\text { Reference } \\
\text { number }\end{array}$ \\
\hline $\mathrm{Y}(\mathrm{III})$ & 150 & 98.3 & & \\
$\mathrm{Th}(\mathrm{IV})$ & 50 & 98.8 & Arsenazo III & 40 \\
$\mathrm{Y}(\mathrm{III})$ & 150 & 99.4 & & \\
$\mathrm{U}(\mathrm{VI})$ & 50 & 98.4 & PAR & 41 \\
$\mathrm{Y}(\mathrm{III})$ & 150 & 99.7 & & \\
$\mathrm{Zr}(\mathrm{IV})$ & 150 & 98.5 & Alizarin red S & 39 \\
$\mathrm{Y}(\mathrm{III})$ & 150 & 99.5 & & \\
$\mathrm{Nb}(\mathrm{V})$ & 50 & 98.9 & PAR & 41 \\
$\mathrm{Y}(\mathrm{III})$ & 150 & 99.6 & & \\
$\mathrm{La}(\mathrm{III})$ & 60 & 99.7 & Arsenazo I & 43 \\
$\mathrm{Y}(\mathrm{III})$ & 150 & 99.3 & & \\
$\mathrm{Nd}(\mathrm{III})$ & 60 & 100 & PAR & 42 \\
$\mathrm{Y}(\mathrm{III})$ & 150 & 98.8 & & \\
$\mathrm{Ce}(\mathrm{IV})^{\mathrm{a}}$ & 50 & 99.0 & Arsenazo III & 40 \\
$\mathrm{Y}(\mathrm{III})$ & 150 & 99.4 & & \\
$\mathrm{Gd}(\mathrm{III})$ & 75 & 99.28 & Arsenazo I & 44 \\
\hline \hline
\end{tabular}

${ }^{\mathrm{a}}$ masked with $10 \mathrm{mg} \mathrm{F}^{-},{ }^{\mathrm{b}}$ Average of six determinations. 
tion and determination of yttrium(III) from binary and synthetic mixture of associated metal ions. The extraction mechanism corresponds to an anion exchange, in which a complex of stoichiometric formula $\left[\mathrm{RPh} \mathrm{NH}{ }_{2}^{+} \mathrm{Y}\left(\mathrm{C}_{7} \mathrm{H}_{4} \mathrm{O}_{3}\right)_{2}{ }^{-}\right]$ (org) is formed in the organic phase. The used solvent, xylene, is less toxic and quite suitable for applied method. The extraction reagent, $N$ $n$-octylaniline, can be synthesized at low cost, with high yield and purity.

Acknowledgements: Mr. B. N. Kokare is grateful to University Grants Commission, New Delhi, for providing financial assistance. The authors thank to UGC-SAP and DST-FIST for financial support for this research work.

\section{REFERENCES}

[1] M.H. Chhatre, V.M. Shinde, Analytical separation of scandium(III) from yttrium(III) and lanthanum(III) by tributyl phosphine oxide (TBPO), Sep. Purif. Technol. 17, 117-124 (1999).
[2] M.H. Chhatre, V.M. Shinde, Separation of scandium(III) and yttrium(III) by tris(2-ethylhexyl)phosphate (TEHP), Talanta 47, 413-419 (1998).

[3] D. Wu, C. Niu, D. Li, Y. Bai, Solvent extraction of scandium(III), yttrium(III), lanthanum(III) and gadolinium(III) using cyanex 302 in heptane from hydrochloric acid solution, J. Alloys Compd. 374, 442-446 (2004).

[4] M. Karve, B. Vaidya, Selective separation of scandium(III) and yttrium(III) from other rare earth elements using cyanex 302 as an extractant, Sep. Sci. Technol. 43, 1111-1123 (2008).

[5] B. Gupta, P. Malik, A. Deep, Solvent extraction and separation of tervalent lanthanides and yttrium using Cyanex 923, Solvent Extr. Ion Exch. 21, 239-258 (2003).

[6] M.L. P. Reddy, R.L. Varma, T.R. Ramamohan, K.S. Sahu, V. Chakravortty, Cyanex 923 as an extractant for trivalent lanthanides and yttrium, Solvent Extr. Ion Exch. 16, 795-812 (1998).

[7] E. Antico, A. Masana, M. Hidalgo, V. Salvado, M. Iglesias, M. Valiente, Solvent extraction of yttrium from chloride media by di(2-ethylhexyl)phosphoric acid in kerosene. Speciation studies and gel for-

$\mathrm{T}$ a b 1 e 4

Separation of yttrium(III) from synthetic mixtures corresponding to commonly associated metal ions

\begin{tabular}{|c|c|c|c|c|}
\hline \multicolumn{2}{|c|}{ Composition of mixture } & \multirow{2}{*}{$\begin{array}{l}\text { Yttrium(III) mass found } \\
\mu \mathrm{g}\end{array}$} & \multirow{2}{*}{$\mathrm{R}(\%)^{\mathrm{a}}$} & \multirow{2}{*}{$\operatorname{RSD}(\%)$} \\
\hline Ion & metal mass $/ \mu \mathrm{g}$ & & & \\
\hline Y(III) & 150 & & & \\
\hline $\mathrm{Fe}(\mathrm{III})$ & 60 & 148.8 & 99.2 & 0.33 \\
\hline $\mathrm{U}(\mathrm{VI})$ & 50 & & & \\
\hline Y(III) & 150 & & & \\
\hline $\mathrm{Ce}(\mathrm{IV})^{\mathrm{b}}$ & 50 & 149.4 & 99.6 & 0.10 \\
\hline La(III) & 60 & & & \\
\hline Y(III) & 150 & & & \\
\hline $\mathrm{Fe}(\mathrm{III})$ & 60 & 148.8 & 99.2 & 0.20 \\
\hline $\mathrm{Zr}(\mathrm{IV})$ & 150 & & & \\
\hline Y(III) & 150 & & & \\
\hline $\mathrm{U}(\mathrm{VI})$ & 50 & 149.1 & 99.4 & 0.20 \\
\hline Th(IV) & 50 & & & \\
\hline Y(III) & 150 & & & \\
\hline $\mathrm{Ca}(\mathrm{II})$ & 40 & 149.0 & 99.3 & 0.31 \\
\hline $\mathrm{Fe}(\mathrm{III})$ & 60 & & & \\
\hline Y(III) & 150 & & & \\
\hline $\mathrm{Fe}(\mathrm{III})$ & 60 & 148.8 & 99.2 & 0.27 \\
\hline Th(IV) & 50 & & & \\
\hline
\end{tabular}

${ }^{\text {a} A v e r a g e ~ o f ~ t r i p l i c a t e ~ a n a l y s i s, ~}{ }^{\mathrm{b}}$ masked by $10 \mathrm{mg}$ fluoride 
mation, Anal. Chim. Acta 327, 267-276 (1996).

[8] F. Bunu, R. Dumitrescu, Simultaneous extraction of rare earth elements and uranium from phosphoric acid, Hydrometallurgy 28, 331-338 (1992).

[9] M. Iglesias, E. Antico, V. Salvado, A. Masana, M. Valiente, Effect of Y(III) distribution between aqueous nitrate and organic D2EHPA solutions on Y(III) precipitation stripping using oxalic acid, Solvent Extr. Ion Exch. 17, 277-300 (1999).

[10] S. Nishihama, T. Hirai, I Komasawa, Selective extraction of yttrium from a Ho/Y/Er mixture by liquid-liquid extraction in the presence of a watersoluble complexing agent, Ind. Eng. Chem. Res. 39, 3907-3911 (2000).

[11] X. Sun, J. Zhao, S. Meng, D. Li, Synergistic extraction and separation of yttrium from heavy rare earths using mixture of sec-octylphenoxy acetic acid and bis(2,4,4-trimethylpentyl) phosphinic acid, Anal. Chim. Acta 533, 83-88 (2005).

[12] Y.G. Wang, S.T. Yue, D.Q. Li, M.J. Jin, C.Z. Li, Solvent extraction of scandium(III), yttrium(III), lanthanides(III), and divalent metal ions with secnonylphenoxy acetic acid, Solvent extr. Ion Exch. 20, 701-716 (2002).

[13] X. Sun, Y. Wang, D. Li, Selective separation of yttrium by CA-100 in the presence of a complexing agent, Proceedings of Rare Earths'04 in Nara, Japan, J. Alloys Compd, 408-412, 999-1002 (2006).

[14] Y.G. Wang, Y. Xiong, S.L. Meng, D.Q. Li, Separation of yttrium from heavy lanthanides by CA- 100 using the complexing agent, Talanta 63, 239-143 (2004).

[15] Y.K. Agrawal, S.K. Menon, S. Sudhakar, Solvent extraction and separation of yttrium with dibenzo-18-crown-6, Sep. Purif. Technol. 24, 197-203 (2001).

[16] W. Li, X. Wang, S. Meng, D. Li, Y. Xiong, Exctraction and separation of yttrium from the rare earths with sec-octylphenoxy acetic acid in chloride media, Sep. Purif. Technol. 54, 164-169 (2007).

[17] J.S. Preston, Solvent extraction of the trivalent lanthanides and yttrium by some 2-bromoalkanoic acids, Solvent Extr. Ion Exch. 12, 29-54 (1994).

[18] J.S. Preston, A.C. Du Preez, Synergistic effect in solvent extraction system based on alkyl salicylic acids III. Extraction of the trivalent lanthanides and yttrium from chloride media in the presence of dialkyl and diaryl sulphoxides, Extr. Ion Exch. 14, 755-772 (1996).
[19] D. Czakis-Sulikowska, N. Pustelnik, A. Malinowska, B. Kuznik, Solvent extraction of yttrium(III), gadolinium(III), terbium(III), thulium(III) and ytterbium(III) with 5,7-dichloro-8-hydroxyquinoline from water and water-methanol solutions, Chem. Anal. 42, 23-25 (1997).

[20] D.K. Singh, H. Singh, J.N. Mathur, Extraction of rare earths and yttrium with high molecular weight carboxylic acids, Hydrometallurgy 81, 174-181 (2006).

[21] A. Shimada, T. Yaita, H. Narita, S. Tachimori, K. Okuno, Extraction of lanthanide(III) ions with $N$, $N$ '-dimethyl- $N, \quad N$ '-diphenylpyridine-2,6-dicarboxyamide (DMDPhPDA) from nitric acid solution, Solvent Extr. on Exch. 22, 147-161 (2004).

[22] J.S. Preston, A.C. Du Preez, Solvent extraction of the trivalent lanthanides and yttrium from nitrate media by dialkyl sulphoxides, Solvent Extr. Ion Exch. 19, 581-595 (2001).

[23] M.R. Yaftian, M. Vahedpoor, M. Burgard, D. Matt, Solvent extraction and transport of rare earth metal ions using 5,11,17,23-tetra-tert-butyl-25,27-bis (diethylcarbamoyl methoxy)-26,28-dihydroxycalix[4] arene, Iran. J. Chem. \& Chem. Eng. 19, 60-64 (2000).

[24] F. Kubota, K. Shinohara, K. Shimojo, T. Oshima, M. Goto, S. Furusaki, T. Hano, Extraction of rare earth metals by calyx[4]arene solubilised in AOT reversed micellar solution, Sep. Puri. Technol. 24, 93-100 (2001).

[25] D.D. Desai, V.M. Shinde, Liquid anion-exchange extraction and separation of yttrium, neodymium and samarium, Anal. Chim. Acta 167, 413-417 (1985).

[26] A.G.I. Dalvi, C.S. Deodhar, B.D. Joshi, Chemical separation and spectrographic estimation of rare earths and yttrium in $\mathrm{PuO}_{2}$ and $(\mathrm{U}, \mathrm{Pu}) \mathrm{O}_{2}$, Talanta 24 (1977), 143-145.

[27] S. A. Sayed, T. A. Sami, A. A. Abd EI Tawab, Synergistic extraction of some rare earths(III) from nitrate media by thenoyltrifluoroacetone and trin-octylamine, Sep. Sci. Technol. 31, 2579-2587 (1996).

[28] O.A. Desouky, A.M. Daher, Y.K. Abdel-Monem, A.A. Galhoum, Liquid-liquid extraction of yttrium using Primene-JMT from acidic sulfate solutions, Hydrometalurgy 96, 313-317 (2009).

[29] A.K. Pyartman, V.V. Lishchuk, V.A. Keskinov, Extraction of thorium(IV), lanthanum(III) and yttrium(III) nitrates with a composite solid extract- 
ant based on a polymeric support impregnated with trialkylamine, Russian J. Applied Chem. 79, 1266-1270 (2006).

[30] A.K. Pyartman, V.A. Keskinov, V.V. Lishchuk, A.V. Konstantinova, V.V. Belova, Extraction of Th(IV), La(III) and Y(III) nitrates with a composite solid extractant based on a polymeric support impregnated with trialkylmethylammonnium nitrate, Russian J. Applied Chem. 79, 1802-1807 (2006).

[31] T.N. Lokhande, M.A. Anuse, M.B. Chavan, Liquid-liquid extraction of palladium(II) with $N$ - $n$-octylaniline from hydrochloric acid media, Talanta 46, 163-169 (1998).

[32] B.M. Sargar, M.M. Rajmane, M.A. Anuse, Selective liquid-liquid extraction of antimony(III) from hydrochloric acid media by $N$ - $n$-octylaniline in xylene, J. Serb. Chem. Soc. 69, 283-298 (2004).

[33] S.S. Kolekar, M.A. Anuse, Selective liquid-liquid extraction of platinum(IV) from ascorbate media by $N$ - $n$-octylaniline: Its separation from associated elements and real samples, Sep. Sci. Technol. 38, 2597-2618 (2003)

[34] S.S. Kolekar, M.A. Anuse, Solvent extraction separation of rhodium(III) with $N$ - $n$-octylaniline as an extractant, Talanta 58, 761-771 (2002).

[35] M.M. Rajmane, B.M. Sargar, S.V. Mahamuni, M.A. Anuse, Solvent extraction separation of zirconium(IV) from succinate media with $N$ - $n$ octylaniline, J. Serb. Chem. Soc. 71, 233-234 (2006).
[36] B.M. Sargar, M.A. Anuse, Liquid-liquid extraction of tellurium(IV) with $N$ - $n$-octylaniline in halide medium and its separation from real samples, Talanta 55, 469-478 (2001).

[37] F.J. Welcher, The Analytical Uses of Ethylenediamine tetraacetic Acid, D.Van Nostrand Company Inc. New York, London, 1958, pp. 50, 185.

[38] Z.G. Gardlund, R.J. Curtis, G.W. Smith, Influence of molecular structural changes on the mesomorphic behavior of benzylideneanilines, Liquid Crystals Ordered Fluids Liq., Crystals Ordered Fluids 2, 541-545 (1973).

[39] E.B. Sandell, Colorimetric Determination of Traces of Metals, Interscience Publishers Inc. New York, London, Third Edition, 1965, pp. 748, 969.

[40] M. Zygment, Spectrophotometric determination of Elements, John Wiley and Sons. Inc. New York, First Edition, 1976, pp. 442, 443, 540.

[41] H.A. Flaschka, A.J. Barnard Jr, Chelates in Analytical Chemistry, Volume 4, Marcel Dekker Inc., New York, 1972, pp. 148, 162.

[42] K.N. Munshi, A.K. Dey, Spectrophotometric determination of rare earth metals with 4-(2- pyridylazo) resorcinol, Anal. Chim. 36, 2003-2004 (1964).

[43] S. Shibata, F. Takerchi, T. Matsumae Spectrophotometric determination of lanthanum(III) with Neothoron, Anal. Chim Acta, 21 177-181 (1959).

[44] M.R. Shivade, V.M. Shinde, Extraction of gadolinium with liquid ion exchangers, Fresenius Z. Anal. Chem. 317, 792-795 (1984). 